\title{
Muslim Cosmopolitans? Transnational Life in Northern Pakistan
}

\section{MAGNUS MARSDEN}

This article explores the importance of transnational forms of Muslim cultural identity in northern Pakistan. By documenting the dynamism of a transnational form of Muslim identity that encompasses people belonging to a wide range of ethnic communities and Islamic doctrinal traditions, as well as extending across countries whose Muslim peoples have experienced the differential effects of their incorporation into both the Soviet Union and British India, the author seeks to challenge the work of Islam specialists who emphasize the centrality of "globalizing modernity" to the making of contemporary forms of Muslim identity. In contrast, this article builds on historical accounts of premodern forms of Muslim cosmopolitanism, notably Engseng Ho's study of Hadrami Muslim scholars who saw themselves as active creators of a universal world structured around the transregional ideals of their faith in the expansive Indian Ocean trading world. Building on this and other work on cosmopolitanism, the author documents the ways in which older experiences of mobility in this politically sensitive region of the world influence villagers' present-day engagements with globalizing processes. The ethnographic focus is on the ways in which Sunni and Shi'a Ismai'li Chitrali Muslims interacted with refugees into their region from Afghanistan and Tajikistan between 1979 and 2002, a time when both countries were experiencing violent civil and international conflict.

$\mathrm{T}$ HIS ARTICLE DRAWS ON my ethnographic work in villages and small towns in the mountainous Chitral region of northern Pakistan. Chitral is populated predominantly by Khowar-speaking Sunni and Ismai'li Muslims but shares a long border with Afghanistan, which, especially since the start of violent conflict in Afghanistan in the 1970s, has been exceptionally porous. Since 1979, Chitral has been home to thousands of permanent and semipermanent Afghan refugees (muhajiran). In addition, the region saw an influx of significant numbers of men from Tajikistan who fled their country after the collapse of the Soviet Union in 1991, when a civil war raged between rival regional factions seeking to secure power in Dushanbe. These transregional movements of people cut across the spatial configurations of post-Soviet Central Asia and postcolonial South Asia and challenge the relevance of these for understanding Muslim life in the region.

Magnus Marsden (mm101@soas.ac.uk) is a Lecturer in Social Anthropology with reference to South and Central Asia in the Department of Anthropology and Sociology at the School of Oriental and African Studies, London. 
My interest in these connections led me to travel to Tajikistan and Afghanistan in 2005 in order to meet men who had once been "refugees" in Chitral yet who, between 2001 and 2003, had mostly returned to their "homelands" (watanan). During my stays in Chitral, I often meet and talk to "refugees" who live there. Their presence is a focus for much discussion among Chitralis, who often accuse these folk of having introduced "simple" Chitralis to a range of moral vices, most notably heroin addiction. Yet all the Chitralis I know also emphasize the important cultural and familial connections that exist between Chitral and a wide range of ethnolinguistic communities living in neighboring regions of Afghanistan and Tajikistan.

My concern here is with what Vinay Gidwani and K. Sivaramakrisnan (2003) call "invisible histories of movement" between remote villages in an expansive extranational mountain realm. This realm, however, lies at the "fringes of the intellectual frameworks known as 'area studies" (Van Schendel 2002a, 647), and its people have experienced the divisive effects of the geopolitics of the Cold War. As a result, few scholars consider either the connections between Muslims inhabiting the peripheries of South and Central Asia or the ways in which these illuminate the nature of Muslim thought and self-understanding in these settings and beyond. As is often noted in the case of other borderlands, it would be tempting to think of Chitrali Muslims as, above all else, living at the margins of the Pakistan nation-state and on the periphery of South Asia. In contrast, this article "jumps scale" (Van Schendel 2002a) by considering the wider regional and analytical significance of relationships between Chitrali Muslims and their neighbors in Tajikistan and Afghanistan.

A consideration of these transregional ways of being Muslim points toward the significance of "identifications, hybrid identities, diasporic existences, minorities, and marginal communities" (Navaro-Yashin 2002, 74) that remain overlooked in much work on Islam within and beyond South Asia’s Muslim societies. In particular, there is a growing body of work that gives the impression that the most salient extranational forms of "Muslim identity" in Pakistan are abstract, religious, created through the processes of globalizing modernity, and tied to the displacement of older local identity registers (Roy 2004). Yet these studies tend to overlook the role played by transregional dynamics in the shaping of South Asian ways of being Muslim and both personal and collective forms of self-understanding. " The significance of work on "global Islam," moreover, has been further enhanced by the terrorist attacks of September 11, 2001 - an event that injected new relevance into understanding the so-called radicalization and globalization of Muslim identities. The emergence of this new gatekeeping concept for the study of Islam in South Asia, and more

\footnotetext{
${ }^{1}$ Anthropological studies of transnational life in a range of culturally fractured border zones often deploy their ethnographic findings in order to question the "naturalness" of the nation as a category of analyses (Gupta 1992, 64; Van Schendel 2002a, 139).
} 
particularly Pakistan, has meant that ways of being Muslim that are neither local and vernacular nor fluid and limitlessly global are rarely the focus of sustained investigation. What I also seek to emphasize, however, is that documenting the multidimensionality of everyday Muslim identifications in a transregional setting that traverses Central and South Asia contributes to rather than challenges older debates about the importance of bounded distinctions to Muslim life. $^{2}$

My concern with transregional forms of mobility and the forms of personal and collective Muslim self-understanding they stimulate connects the findings presented here to anthropological work that theorizes types of identity "imaginings" that are wider in scope than national, subnational, or ethnic (Gupta 1992; see also Bayly 2004a, 2004b; Ho 2002). Much of this work addresses the opportunities and problems posed by terms such as "globalization," "cosmopolitanism," and "transnationalism" for analyzing "folk understandings of the global, and the practices with which they are intertwined" (Tsing 2002, 469). Many anthropologists, for example, have contested the scholarly tendency to associate working-class migrants exclusively with transnationalism, claiming that doing so denies such people the possibility of embodying an "open-endendness" of cultural vision (Werbner 1999). Cosmopolitanism and "open-ended" "subjectivities" that enhance "potentialities for engagement with 'otherness" (Humphrey, Marsden, and Skirvskaja, forthcoming), Pnina Werbner suggests, remain associated with global cities and elites or places claimed by international trade and the global traffic in meaning (Appadurai 1996; cf. Ferguson 1999, 211-21; Hannerz 1996; see also Das and Poole 2003; Gidwani and Sivaramakrishnan 2003; Gupta 1992; Pollock 2004; Tsing 2005; Van Schendel 2002b; Wilson and Donnan 1998). As a result of these debates, there is now a wider recognition among anthropologists of the ways in which open-ended subjectivities may emerge from rural-rural migrations as much as they do from transnational movement (Gidwani and Sivaramakrisnan 2003). Other scholars, however, have pointed toward the danger of treating cosmopolitanism as simply reflecting the "celebration of cultural sophistication." Instead, they define cosmopolitanism as a discursive devise through which "a specific and exclusive local identity" is "objectified and valorised" (Osella and Osella 2007). Likewise, Anna Tsing has argued that by focusing on "historically specific collaborations" rather than interactions between "globalizing" forces and "local" visible in the simultaneous production of ideal forms of cosmopolitan, openness for engagements with "otherness" and more vernacular forms of collective self-understanding are made visible. Repeated interactions between people from different backgrounds, she suggests, create "new interests

${ }^{2}$ I build on Mathijs Pelkmans's call in his study of the Turkey-Ajaria border for the need to "move beyond the discussion of whether borders are best defined in terms of fluidity or rigidity and examine how these aspects are ultimately interconnected" $(2006,13)$. 
and identities" that are never to "everybody's benefit" (2005, 126; see also Pollock 2004, 19-20).

What I find most useful about these debates about cosmopolitan forms of selfunderstanding that are neither local, national, nor global is their recognition of the ways in which even exclusive forms of identity arise from wider links, a process that Engseng Ho refers to as "resolute localism" (2006, 68). Exclusive forms of self-understanding, moreover, are not only the product of interactions between openness and closedness: They are also often purposefully injected with a sense of cosmopolitanism. This article, too, explores a highly particularistic set of cosmopolitanism practices as they are enacted by Muslims living in a particular setting. By documenting the ways in which village Muslims negotiate diverse registers of allegiance and identity during the course of their daily lives, I seek to draw attention to the complexities of Muslim life in a territorially porous and internally diverse region, and to the important role that local practices and discourses of cosmopolitanism play in shaping these negotiations. These practices lead to the production of exclusive interests and identities. At the same time, they also call on the region's people to switch between very different indexes of being Muslim.

Anthropological work on Islam has been enriched in recent years by studies focusing on the historical dynamism of connective Muslim life and the role of these in Islam's constitution as a world religion (cf. Bowen 1998). Many studies focus on avowedly religious yet dispersed forms of translocal diasporic networks, such as those embodied in Sufi brotherhoods (Werbner 1999, 2004) or global movements of Islamic reform and purification (Mandaville 2004; Metcalf 1999). Others theorize about the ways in which the circulation of long-distance traders, pilgrims, and holy men of religious authority all contribute to a shared sense of Muslim community and the making of transcultural Islamic spaces or ecumenes (Ho 2006, 100). Much of this work focuses on "coastal Muslims" living in the expansive Indian Ocean region and argues that transregional ways of being Muslim in such littoral spaces have been long overshadowed by works that explore Muslim life in the so-called heartland of Islamic textual in northern India (Didier and Simpson 2005, 43). ${ }^{3}$

In Chitral, too, connective ties of kin, trade, and religious knowledge are all central to the making of transregional forms of Muslim collective identity that challenge conventional core-periphery models of the sacred geography of Asian Islam. ${ }^{4}$ This article adds to these studies by exploring the ways in which

\footnotetext{
${ }^{3}$ For comparative studies of other transregional spaces that cut across more conventional representations of cultural "areas," see Bruce Grant (2005), Engseng Ho (2002, 2004, 2006), Seteney Shami (2000), Edward Simpson (2006), and Willem van Schendel (2002a). See Benjamin F. Soares (2005) and Robert Launay (1992) for considerations of transregional Muslim identities in West Africa. ${ }^{4} \mathrm{By}$ focusing on an expansive mountain range that cross-cuts nation-states, is connected by networks of overland trade routes, and is made up of doctrinally and linguistically diverse valley communities, I aim to show that mountain as well as coastal regions afford complex opportunities for the instantiation of forms of sociality that are highly attuned to the negotiation of religious plurality.
} 
such forms of interconnectivity have interacted with another very different type of transnational mobility: refugee flows generated by violence, Afghanistan's fragmentation, and the breakup of the Soviet Union. Pakistan's North-West Frontier Province has been profoundly affected by political instability, military conflict, and displacement over the past three decades, making it an especially rich setting for the study of transnational dynamics of Muslim self-understanding. Most anthropological work on "refugees" in Pakistan focuses on "displaced persons" living in "camps" (Shahrani 1995). "Uprooted" Afghans living a life divided between camps and the frontier's reformist Deobandi madrasas are widely recognized as playing a critical role in the emergence of de-territorialized forms of "Muslim identity," the displacement of older identity registers, and the so-called radicalization of Frontier Muslim identities (notably Kepel 2002; Roy 2004; see also Roy 1994; Roy and Zahab 2004). There is now a growing appreciation of the diversity of the Afghan refugee experience in Pakistan (Monsutti 2006). The implications of this diversity, however, for the tenor of religious and cultural life in Pakistan has remained largely unexplored. ${ }^{6}$

Thus, this article emphasizes the ways in which people's older experiences of mobility in a culturally complex world shape their current experiences of transregional movement (Shami 2000, 189). Chitralis talked about and interacted with men from Tajikistan and Afghanistan who lived and worked in their village in diverse and complex ways. These incomers were not simply treated as rootless "refugees" but as relatives, friends, and named persons who carried languages, cultural practices, and unique forms of religious knowledge, as well as workers and servants with shared histories of participation in culturally connected realms of labor.

\section{Sulton's Story}

Sulton came to Chitral from the southern Gorno-Badakshan region of Tajikistan in December 1999, two years after the cessation of full-scale military conflict there but during a period of great economic hardship and political uncertainty.

\footnotetext{
${ }^{5}$ On camp-based refugees in Pakistan, see M. Nazif Shahrani (1995); cf. Michael Hutt (2005) on Bhutan's refugee community in Nepal. For a notable exception, see David B. Edwards (1990, 1994). My work differs from Edwards's work on Pakistan-based Afghan refugees in Pakistan in that I focus on the interactions between Afghan refugees and Pakistani Muslims in a local setting. ${ }^{6}$ There is an expanding body of literature by development-focused researchers based in Afghanistan (e.g., Abbasi-Shavazi and Glazebook 2006; Collective for Social Science Research 2006a, 2006b; Habibi and Hunt 2006; Stigter 2005), as well as more analytical treatments of the problems associated with the "repatriation" of Afghan refugees to the country today (Turton and Marsden 2002; Monsutti 2006). The focus of these studies, however, is concerned more with the livelihood strategies of refugees than with the implications that such forms of mobility have for understanding the interconnected cultural and religious dynamics of life in Afghanistan and neighboring countries today.
} 
His mother tongue is an Iranian-Pamiri language, Shughni, but he also speaks Tajiki Farsi, Russian, and now Khowar and Dari (Afghan Farsi). On his arrival in Chitral, a member of the family with whom I stay found him on a cold winter's night outside one of the village's places of Ismai'li worship. Like the Khowar-speaking Chitrali family with whom we both stayed, Sulton is a Shi'a Ismai'li Muslim. During his first months in Chitral, Sulton frequently told the family, themselves descendents of influential pirs (spiritual authorities), that it was his search for Ismai'li religious knowledge that had motivated him to embark on his journey to Chitral: Ismai'lis in Tajikistan, he said, had little knowledge about Ismai'li doctrine as a result of the antireligion policies of the Soviet Union, and he wanted to return home with a certificate of Ismai'li education.

Sulton's stay in Chitral would not result in him acquiring any abstract sense of affiliation with a shared Ismai'li communal identity, however. Sulton spent most of his days collecting water, threshing wheat, chopping wood, and even planting roses; yet his is stay in the village was eventful. He was known as "hot headed" by the villagers. On one occasion, for instance, he gave a village boy, Aftab, who had a reputation for being something of a loafer-a result of his public attempts to meet girls and his fondness for shamelessly smoking hashish in the village lanes_a sound beating over a disagreement concerning the division of the village's scant water supplies. Sulton also fell out with the Ismai'li family with whom he stayed: He accused them of putting him to work but teaching him nothing about religion. One evening, he fought with the family's younger brother, saying, "I have come to Pakistan to go back with something and not to be treated like your slave." He left the home, now pursued also by the village police, who were threatening to charge him with assault, and never returned.

On September 8, 2001, I met Sulton again, this time on the polo ground at the region's administrative headquarters, Markaz. Sulton had radically transformed his personal appearance: When first in Chitral, like most other men from Tajikistan, he had worn Western-style trousers and had been clean shaven; now, he appeared bearded and dressed in shalwar kamiz. He also pointed in the direction of the group of men who had accompanied him to the ground. Bearded and donning black turbans, they were, he told me, Afghan Taliban based in the city of Jalalabad; he had been working for them as a driver since leaving Chitral the previous year.

If Sulton had not embraced any abstract commitment to Ismai'li religious knowledge or community during his stay in Chitral, neither had he been unthinkingly Talibanized by his experiences in Afghanistan either. Sitting underneath the cool shade of the famous Chinese Plane tree where Chitrali polo players rest their horses at halftime, Sulton whispered to me that he had not become a Sunni, nor had he renounced his Ismai'li faith. Rather, in the company of his newly found Taliban companions, he merely pretended to be a Sunni. "They don't know I'm an Ismai'li, don't tell them," he told me. The dissimulation (taqiya) of adherence to Ismai'li doctrine and practice is a marked feature of historical and 
present-day Ismai'li experience. What is distinctive about Sulton's case, however, is that it involved an Ismai'li from Tajikistan joining the Taliban, a Sunni and predominantly ethnically Pashtun movement, widely known for its deeply hostile and violent attitudes to Shi'a Muslims. Pretending to be a hard-line Sunni in such an ambient is not a simple task, especially for a post-Soviet Ismai'li. Sunni and Shi'a Ismai'lis pray in very different ways, and Sulton told me that he stood at the back of gatherings and imitated his Taliban bosses as best he could. I noticed these men leaning on their plush new Toyota Hilux, gazing at Sulton and myself chatting, and decided that this was not the place to linger. Instead, I returned to the polo ground and watched the equally captivating spectacle of the game between the Chitral Police and the Chitral Scouts descending into a physical brawl involving players and their uniformed supporters alike, an event that would lead to curfew being imposed in the town the following day.

After September 11, I lost touch with Sulton but often wondered what had happened to him. In March 2002, I was informed that Sulton had returned to Chitral. He was now said to be working in the house of a man from a one-time noble (adamzada) background, known as a lord (lal) across the region, and who owned, by Chitrali standards, a substantial amount of land in a relatively remote village to the north of the region. This lal was a Sunni, although he was also known throughout Chitral for expressing near blasphemous statements. He also had a well-earned reputation for being Chitral's most prolific hashish producer, and it was now rumored that he was diversifying his smuggling activities into apricot schnapps-the production of which my former Talib friend, Sulton, was said to be investing his talents, to great effect.

The next time I met Sulton was with the aforementioned lord on a snowy afternoon in December 2005. We arranged to meet at dusk on the polo ground, where Sulton told me that he felt he was now the proverbial "prisoner of the mountains" (zomo qaidi): If he returned to Tajikistan, he would almost certainly be arrested by Tajikistan's security forces, who were suspicious of all people who had fled to Pakistan or Afghanistan during the civil war, and even more suspicious of those who had yet to return. If he traveled to "down Pakistan" (aff Pakistan) in order to meet officials at Tajikistan's embassy, he feared that he would picked up by the Pakistan police, perhaps sent to Guantánamo Bay, or even deported to Tajikistan, where he risked standing accused of illegally leaving his country during the civil war and being harshly treated by its police and intelligence agencies. Sulton then pulled out a bottle of apricot schnapps that he had hidden down his trouser leg and presented it to me as a gift before bidding farewell.

On the one hand, Sulton's story highlights the very different ways in which states are directly involved in the production and regulation of transregional mobility. Sulton's mobility is pervaded by a sense of surveillance by the nation-states through which he travels, and this is often manifested in a fear of their intelligence 
agencies. Moreover, Sulton also recognizes the ways in which very different forms of transnational policing and surveillance-those arising from the United States and the so-called war on terror-add a further layer of complexity to the consequences of his transregional mobility. In spite of such limits, however, more neutral places, notably Chitral, continue to afford him complex opportunities for repeating cycles of arrival, departure, and return. At the same time, Sulton illustrates the importance of types of everyday strategies that anthropologists have long recognized as being characteristic of life in borderlands. He is not merely a nameless refugee, passively buffeted by distant international events but rather embarks on complex courses of action in response to rapidly changing geopolitical circumstances.

Sulton's trickster-like ability to artfully instrumentalize the relationships he builds with Chitrali Ismai'lis, Sunni smugglers, and the Pukhtun Taliban is an important reminder of the social and moral multidimensionality that borderland life may inject into even the most apparently bounded forms of collective identity. Thus, Sulton persuasively switches between different registers of Muslim subjectivity as he moves through the region. Ho has described the history of the Yemeni Hadrami diaspora in relationship to a "landscape of places that closed or opened" to different categories of people in relationship to "internal divisions" and "external rivalries" (Ho 2006, 314). Sulton's Chitral odyssey illustrates exactly the type of work deployed by people who move through such shifting moral landscapes, which are divided by colonially imposed boundaries and invested with shifting forms of global political significance. A wily frontier strategist and a sophisticated mountain cosmopolitan, Sulton affords us a unique glimpse into the making and working of actual cosmopolitanism on the Pakistan-Afghan frontier.

\section{The Setring}

A region known today primarily because of the ongoing search for al-Qaeda militants, the war on terror, and heroin cultivation, few appreciate the degree to which northern Pakistan, northeast Afghanistan, and southern Tajikistan form an interconnected region of the Muslim world that is remarkably diverse in relation to its size and sparsely populated terrain. ${ }^{7}$ This section explores the ways in which all these societies are historically connected and the importance of these for understanding the region today.

I was aware throughout my fieldwork in Chitral that Chitrali Muslims have a strong sense of identification with a broad transnational region that is similar in important ways to what historians of precolonial India describe as a "Persianate" realm. Historians conceptualize this Persianate realm as defined not only by the

\footnotetext{
${ }^{7}$ A notable exception is Hermann Kreutzmann's (2003) sophisticated exploration of the changing economic and political fortunes of the region's high mountain farmers and pastoralists.
} 
importance of Persian as a language of political authority and high culture but also in relationship to its shared literary traditions (Cole 2002; Mir 2006). The Persianate world was not a homogenous, static, or territorially bounded cultural entity. It was defined, rather, by ongoing cultural interchange between India and Iran (Cole 2002) and with Turkic-speaking regions of Central Asia (Canfield 1991). These complex processes of exchange led to the creation of important "hierarchies of culture" (Alam and Subrahmanyam 2007, 177) within and across a region that incorporated both Indian urban centers, notably Delhi and Lucknow, as well as rural regions of Central Asia (Shahrani 1991). Nevertheless, Persianate societies shared similar types of political authority defined by a marked focus on kingship, distinctions between commoners and aristocrats, and a courtly, literate, bureaucratic tradition (Alam 2004; Alam and Subrahmanyam 2004).

Persianate forms of sociality, governance, and high culture formed a critical dimension of everyday life in the expansive region on which I focus here. Throughout much of the nineteenth century, each of these regions was once a quasi-monarchical state, or princely kingdom incorporated into a central Asian khanate. ${ }^{8}$ The fiefdoms of Gorno-Badakshan of present-day Tajikistan were, until the expansion of the Soviet Union, embedded within tributary relationships with the emirate of Bukhara (see Becker 1968). The kingdom of Afghan Badakshan was enmeshed in a shifting relationship with the centralizing Afghan state (Noelle 1997), while the territorial boundaries of the Chitral princely kingdom, which was part of both tributary and conflictual relations with the "states" of Badakshan and Kashmir, constantly shifted in relationship to the factional succession disputes within the region's "ruling family" (Biddulph 1972; IUCN Pakistan 2004).

The ruling families of many of these realms enjoyed a very high degree of shared kinship with one another. At the same time, it was also a region of intense instability provoked by ongoing factional struggles within and between the region's "states," where the flight and exile of rulers and princely contenders to courtly power was a widely deployed political strategy (Parkes 2001a). ${ }^{9}$ These migrations also included the carriers of Persianate linguistic and cultural practices, including poets from the court of Kabul who "wrote the history of Chitral in Persian poetry," composed praise poetry in honor of its Mehtar, or ruler, and taught the court's children Persian (Murtaza 1982, 319).

\footnotetext{
${ }^{8}$ These mountain kingdoms also existed on the frontiers of the Mughal Empire, and, as with other dry zones in Iran, Afghanistan, and Central Asia, have long been intimately connected with the history of India (see Gommans 2002). For an overview of Chitral's historiography, see Wolfgang Holzwarth (1996).

${ }^{9}$ The realm as a whole may be compared to Stanley J. Tambiah's (1976) model of Southeast Asian "galactic polities." Court histories of Chitral document the crisscrossing migration of men and their families descended from the ruling families of neighboring states, especially Badakshan (Murtaza 1982, 302; see also Kreutzmann 2003, 220).
} 
This political interconnectivity was further enhanced by flows of people between these polities before and shortly after the expansion of Russian and British colonial power in the region. ${ }^{10}$ Population movement included traders and pilgrims en route to Mecca from Chinese Turkestan (Shahrani 2002, 41). Complex systems of patronage that incorporated quasi-aristocratic gentry elites and folk described as "serfs" (chirmuzh) and "servants" (khidmatgaran), in Khowar and tenants (dehqan) in Dari were central to the region's political economy. Such people often moved with the region's interrelated lordly elite whom they served (Staley 1982). The transfer of "slaves," moreover, between these mountain realms (Hopkins, forthcoming), is another shared dimension of past experience for the region's people, the legacy of which continues to be a sensitive topic of debate today.

In what ways have the cultural forms of this courtly Persianate been reformed within the context of South Asia's modern nation-states? (Ali 2004, 3; Parkes 2001b; Staley 1982, 153-54). Many scholars have argued that the divisive effects of colonialism and nationalism obscured the range of ties that had once connected this diverse Indo-Persian realm (Cole 2002, 31). Others suggest that premodern Persianate traditions have been stripped of their vitality and rendered an apolitical part of South and Central Asia’s "national cultures." Yet despite now being a fully integrated part of the Pakistan nation-state, many Chitrali Muslims continue to speak and read Farsi. There is a very strong tradition in Chitral of the performance of Khowar love songs, which are deeply influenced by Persianate ghazal poetry. In recent years, moreover, many Chitralis have told me that the region's poets are using more and more complex Farsi words and phrases in their writing. Much social science literature on Pakistan focuses on the Punjabization of the country's cultural and political life (Jaffrelot 2002). Yet Chitralis talk about processes that could be described as the Farsization of their popular culture. Chitralis who speak Farsi, moreover, are not confined to elderly and noble men educated during the final days of the Chitral court-younger men from a wide range of backgrounds have also often learned Dari, most notably from Chitral's Afghan refugees. ${ }^{11}$ At the same time, the region's ulama, or dashmanan, continue to talk about the ability to read religious texts, especially Rumi and Hafiz, in Farsi as a sign of great erudition and a source of unique spiritual insight, despite their own education in reform-minded Urdu and

\footnotetext{
${ }^{10}$ The Norwegian linguist Georg Morgenstierne $(1932,68)$ said that he had met a man from Yamg, an Ismai'li village that is now a part of Tajikistan, in the Chitral bazaar in 1929, pointing toward the continuing interactions between Chitralis and Pamiri Ismai'lis living in the Soviet Union.

${ }^{11}$ Chitralis are conscious of the differences between the types of Farsi spoken in Afghanistan, Tajikistan, and Iran and are also aware of the national linguistic categories "Dari" and "Tajiki." On the whole, however, they say that they are able to speak and read "Farsi"- this is why I refer to Persian, Farsi, Tajiki, and Dari interchangeably throughout this article. On the complexities of the scholarly usage of the terms "Persian," "Farsi," "Dari," and "Tajik," see Brian Spooner (1993).
} 
Pashto-medium madrasas that teach the Islamic sciences above all through the use of Arabic texts.

Almost all Chitralis, moreover, say that Farsi is the "sweetest" language of all and proudly comment that Khowar is more closely related to Farsi than the North-West Frontier Province's de facto language of politics and religion, Pashto. What Chitralis themselves talk about as the expanding significance of Farsi in their region's popular culture has taken place alongside Chitral's political incorporation into the North-West Frontier's political culture over the past thirty years. During this period, Pakistan's so-called Islamist political parties, the leadership of which is predominantly Pukhtun (Nasr 2005), have become a central feature of political life in Chitral. Much of the imaginative work that Chitralis invest in mapping their region as a space influenced by high forms of Persian culture and language, thus, forms a complex local response to the interplay between Islamist and Pukhtun ethnic politics that has shaped many of the political debates in the frontier in recent years.

Yet playing an active role in making and being a part of this extranational cultural space does not simply eclipse the power of more vernacular-like forms of self-understanding rooted in adherence to the diverse and cross-cutting registers of locality, language, and doctrine. For all Rowshan villagers, "being Chitrali" and speaking Khowar are critical reference points that distinguish them from other ethnolinguistic groups in Pakistan and beyond, most especially Pashto-speaking "Pukhtuns." Furthermore, the invisible histories of movement I explore did not take place between a Khowar-speaking Chitral realm, on the one hand, and a generalized Persian-speaking realm, on the other. Diverse registers of linguistic difference and attachment to locality were and remain an active feature of life in the region. Major languages spoken, in addition to the notionally "national" languages of Urdu, Dari, and Tajiki, include a range of Indo-Iranian languages that are, although to widely differing degrees, closely related; these include Khowar, Shughnani, Kalasha, Wakhi, Rowshani, and Yidgah (see Decker 1992; Morgenstierne 1932; Staley 1982).

Nor does Islam define a religious continuum in the region in any simple sense. Two types of Islamic doctrinal traditions are represented in the region: Sunni and Shi'a Ismai'li. Ismai'lis are taught to believe the Aga Khan is the "living Imam," the closest direct descendent of Muhammad and therefore a man of unique spiritual insight and power-he is also referred to as the "talking Qur'an," or qur'an-e natiq (Daftary 1990). ${ }^{12}$ The village people with

\footnotetext{
${ }^{12}$ Shi'a Ismai'lis came into being as a result of a schism over succession to the imamate in 1094, and Ismai'lis differentiate themselves from Ithna 'ashariyya Shi'a Muslims. There have also been a number of doctrinal splits during the course of Ismai'li history (Daftary 1998, 2). The Nizari Ismai'lis are the largest Ismai'li doctrinal cluster. The other Ismai'li community in South Asia is the Tayyibi Ismai'lis, known as the Bohras (see Engineer 1989; Blank 2001). Ismai'lis in Chitral and, indeed, northern Pakistan, are all Nizari Ismai'lis. In Chitral, Shi' a Ismai'lis contrast their modes of theological understanding and experience with those of the region's Sunnis. At one level, what
} 
whom I work are all Khowar-speaking Muslims, yet they categorize themselves as being either Shi'a Ismai'li or Sunni. There have been moments of violent conflict between the followers of these deeply divergent Islamic "doctrinal clusters," both during the colonial period, notably in 1924, and in more recent years in 1982 , 1999, and 2001 (see Marsden 2005).

Although Islam divides as much as it unites the region's Muslims, the Ismai'li Islamic tradition is an important and shared source of faith, self-understanding, and experience, as well as conflict, in all of these settings. Ismai'lis in the region talk a great deal about their collective memories and experiences of "cruelty" (zulm) in the Sunni-majority courtly and latterly nation-states within which they live. In recent years, Ismai'lis in Afghanistan have faced violent attacks by the Sunni mujahidin (see Ehmadi 1993, 1998), which led many of them to flee to Chitral, especially between 1992 and 2001. ${ }^{13}$ In Chitral, too, powerful Sunni religious authorities trained in Pakistan's religious seminaries campaigned throughout the 1990s for the Pakistan state to declare Ismai'lis non-Muslim infidels (kafiran) (Marsden 2005). In 1999, it was widely rumored among Chitrali Muslims that the Aga Khan was considering evacuating all of Chitral's Ismai'lis to Canada in the event of a major upsurge in violent sectarian conflict in the region. Shared experiences and the imagination of flight, thus, are marked features of the collective memory of Shi'a Ismai'lis across all of these diversely constituted realms.

Neither the shared historical memory of Sunni cruelty nor the more recent interactions between Afghan and Chitrali Ismai'lis have resulted in the creation of an elevated sense of Ismai'li internal sameness, however. ${ }^{14}$ Ismai'li religious

distinguishes them from Chitral Sunnis is that they are taught to believe that the Aga Khan or "Present Iman" is the center of Shi'a Ismai'li belief and cosmology, imbued with a special form of spiritual insight and power, and considered to be able to interpret the Qur'an in a way that is impossible for ordinary Muslims. At the same time, they also emphasize the ways in which the Shi'a Ismai'li tradition of Islam focuses particularly on the need to understand the inner (batin) meanings of the Qur'an. Ismai'li Qur'anic interpretation (tafsir) emphasizes the importance of esoteric hermeneutics ( $\left.t a^{\prime} w i l\right)$ in which the surface words of the Qur'an are understood as having a deeper meaning than the doctrines they elicit. In contrast, the region's Sunnis are often said to be above all concerned with "surface level" (tanzil) forms of Qur'anic interpretation (tafsir). The historiography of Shi'a Ismai'lis forms of knowledge, identity, and devotion in Chitral remains contested, although some authors suggest Ismai'li forms of thought and identity may have been important in the region from the early seventeenth century (Holzwarth 1996, 123).

${ }^{13}$ On the Afghan Badakshan's mujahidin and their role in the anti-Soviet resistance movement, see Shahrani (1984).

${ }^{14}$ The influences of transnational forces on Ismai'li ways of being Muslim in Chitral today are complex and often have a more apparently "global" dimension . The Aga Khan is a U.K. citizen based in Paris, while the offices of the Aga Khan Foundation (a major international nongovernmental organization) are located in Geneva. Both of these places form an important part of the religious and geographic horizons of the region's Ismai'li Muslims. The Aga Khan makes relatively frequent visits to Chitral (most recently in December 2003) and other regions of Pakistan, Tajikistan, and Afghanistan with significant Ismai'li populations (see Marsden 2005 for a consideration 
self-understandings, as I have encountered them, are always relationally defined. Interactions among Afghan, Chitrali, and Tajik Ismai'lis, emerging from the porousness of the region's boundaries over the past decade, have contributed to a growing emphasis on Ismai'li internal sameness. Yet, as I will discuss later, this has not inevitably weakened other types of attachment to locality and regional custom. Nor has it created a miniature Ismai'li arch within a broader and rapidly emerging Shi'a crescent, which, according to political scientists such as Vali Nasr (2006), links politically resurgent Shi'a Muslims from Beirut to Lucknow. Rather, the region's Ismai'lis often talk about the cultural differences that distinguish them from one another, but they unite in relationship to Ismai'li communities elsewhere in South Asia, notably Gujerati-speaking Khoja Ismai'lis, who are influential in the offices and institutions of the Aga Khan. ${ }^{15}$ Abstract types of Islamic consciousness are not innate and just waiting to be realized-rather, different types of Muslim self-understanding remain simultaneously important without simply effacing one another.

If modern refugee flows have not simply led to the displacement of regionally distinctive registers of Muslim self-understanding, then neither have they effaced older forms of interregional connectivity. The influx of men from the post-Soviet state of Tajikistan in the late 1990s, in addition to Sunni and Ismai'li Muslims from Afghanistan, adds another layer of complexity to the transregional connections that I am currently exploring. ${ }^{16}$ Chitral became a unique and interactive space that connects the predominantly Muslim societies of postcolonial Pakistan, post-Soviet Tajikistan, as well as "semicolonial" Afghanistan (Goodman 2000; Shih 1996). People whose lives had been divided for nearly a century once again shared the intimate spaces of Chitrali villages. ${ }^{17}$ In October 2005,

of deedar). During the Aga Khan's visit in December 2003, for example, the family of Chitrali Ismai'lis with whom I stay hosted Ismai'li guests from both Tajikistan and Iran.

${ }^{15}$ Ismai' lis in Badakshan and Chitral, however, explain the origin of these differences that divide them from their Khoja brethren as being a product of their affiliation to an Ismai'li spiritual tradition said to be a legacy of the preaching activities of the eleventh-century mystical poet Nasir-e Khusraw (Hunsberger 2000). A complex funeral ritual, the chiragh-e roshan, widely said by Ismai'lis throughout the region to be a direct legacy of the preaching activities of Nasir-e Khusraw, is one especially important diacritical mark deployed the region's mountain Ismai'lis to define themselves in relation to their co-religionists in different settings within and beyond South Asia. Cf. John R. Bowen (1989) for the ways in which Muslims in Sumatra distinguish themselves on the basis of distinctions they make between different modes of performing Islamic daily prayers.

${ }^{16}$ For detailed accounts of Tajikistan's civil war, see especially Shirin Akiner (2002), Shirin Akiner, Mohammad-Reza Djalili, and Frederic Grare (1997), and Adeeb Khalid (2007, 148-53). For a recent study of the textual expressions of the Ismai'li Islamic tradition in the Pamirs during the late nineteenth century, see Abdul Iloliev (2006).

${ }^{17}$ The villages and small towns of the Gorno-Badakshan Oblast did not see major fighting, yet they were subjected to a blockade by Tajik government forces. Pamiri Tajiks, the term widely used to refer to Ismai'lis living in Badakshan, were involved in the civil war. Some Pamiris fought and became especially commanders for the opposition Islamic Movement for Tajikistan (Roy and 
I visited villages in Tajikistan's Gorno-Badakshan Oblast in order to meet Pamiris, the term widely used by the region's people to refer to the Ismai'lis who live in the high mountain villages of both Tajikistan and Afghanistan and who lived in Chitral between 1992 and 1999 as refugees. I was told how they had swum across the Pyanj River into Afghanistan, where they bartered with Afghan Wakhi-speaking villagers for kerosene and aluminum dishes in return for precious Afghan supplies of oil, rice, but also tea from Chitral. ${ }^{18}$ In small groups, they also traversed the Afghan Wakhan corridor and the high passes of the Hindu Kush, eventually reaching Chitrali villages after a three-day walk. Chitral occupied an important place in the geographic and imaginative horizons of all the Pamiris I spoke to. Village elders remember their grandfathers walking to Chitral in order to procure teas, sugar, and salt before their region's incorporation into the Soviet Union. Others told me that their grandmothers were Chitrali, and they could remember the names of the Chitrali villages from where they had come and asked me if I had visited these places. One man even remembered some of the Khowar words that he had been taught by his grandmother as a child. Thus, Tajik men did not simply enter Chitral as displaced persons; they arrived, rather, with previously existing reputations and holding historically informed expectations of the nature of Chitrali life.

Connections between these regions, however, have changed rapidly in relationship to changing geopolitical circumstances. After the American-led defeat of the Taliban government in Kabul in 2002, the Chitral-Afghan border was effectively sealed. The United Nations High Commission for Refugees (UNHCR) and the government of Pakistan also actively pursued initiatives designed to encourage the return of Pakistan-based Afghan refugees to their country. These included the closure of established refugee camps in Pakistan, the relocation of Afghan refugees living in urban settings such as Peshawar to more remote and rural locations elsewhere in the frontier, and the offering of financial incentives by the UNHCR designed to encourage the return of Afghans to Afghanistan. At one level, these changing representations of Afghans living in Pakistan from internationally recognized refugees to nonrefugees stand in contrast to the ways in which the subjectivities and roles

Zahab 2004) against progovernment forces. As a result, Pamiri Tajiks living in Dushanbe were the targets of widespread violent attacks. Consequently, many Dushanbe-based Pamiris sought to escape to their ancestral villages in the Pamirs during the war. Yet the people of Gorno-Badakshan, a region that had hitherto largely depended on Soviet subsidies, were starving as a result of the government blockade of traffic to the region, including humanitarian aid convoys. It was during these years that hundreds of ethnic "Pamiris" from post-Soviet Tajikistan migrated as seasonal laborers and refugees to the villages of Chitral and Pakistan's major cities, especially Karachi, which is also home to a wealthy and vibrant Ismai'li community.

${ }^{18}$ These modern-day forms of "barter" thus invoked older memories of transregional trade in the era before the hardening of the colonial boundaries that divided British India from the Soviet Union (Shahrani 2002). 
of Afghan refugees are understood in complex and multidimensional ways in specific localities in Pakistan. At the same time, they point toward the ways in which nation-states and international organizations have increasingly represented refugees and formulated their policies in relationship to attempts by United States in order to assert a claim of stability in Afghanistan in the wake of the country's invasion in 2001 (Turton and Marsden 2002, 3).

These changes have had important consequences for the livelihoods and personal experiences of the region's mobile mountain Muslims. Since December 2001, few Farsi-speaking Afghan and Tajik peoples have been able to enter Chitral without either Afghan refugee cards or Pakistani visas and internationally valid passports. Some Afghan refugees with legal documentation stayed, but most left. Importantly, many of those who did leave continue to hold Afghan refugee cards; they continue to make frequent returns to Chitral in order to participate in education courses run by small-scale private tuition centers (especially English language and computer training), sell cheap secondhand cars from Afghanistan at higher Pakistan prices, and visit the Chitrali families with whom they lived during the previous thirty years. ${ }^{19}$ Others who remained in the region without proper documentation, as in the case of Sulton, now lived in a region of uncertainty, surrounded by heavily policed boundaries and thrust into the international spotlight after September 11.

The closure of the Afghan-Pakistan border had a profound impact on people's everyday lives. The region's interconnected frontier economy underwent rapid change: Cross-border trade in meat and precious stones, especially lapis lazuli and polo horses from Afghanistan, and kerosene and wheat from Chitral, abruptly ceased. Afghan villagers in Badakshan told me they could neither walk to Chitral nor afford the expensive journey to Kabul. By July 2003, the only Afghans living permanently in Chitral were Sunnis who owned butcher shops and bakeries; many Chitrali shopkeepers complained that the bazaar felt "empty" (khali).

Yet connections between the regions have an uncanny ability to reappear even after the imposition of apparently rigid forms of boundaries: The borders that divide the region's people open as they close. International development nongovernmental organizations, especially the Aga Khan Development Network, have been active in Chitral since 1983 (Parkes 2000); they are now undergoing significant downsizing in Pakistan but are expanding their operations in the postconflict

\footnotetext{
${ }^{19}$ Most "Chitrali Afghans," as they often refer to themselves, have now returned to their country, and the assisted repatriation of Afghans living in Chitral by the UNHCR continued during a visit to the North-West Frontier Province in August 2006. In Kabul, I have met men working in the city's burgeoning guesthouse sector who lived and worked in Rowshan and spoke to me in Khowar. Many other Afghan refugees who ran shops in Chitral's main bazaars, have now opened businesses in Afghanistan's major cities, notably Mazar-e Sharif, Kabul, and Kunduz. Chitrali development professionals working in Afghanistan also talk of the affectionate friendships they have built with Khowar-speaking Afghan men whom they knew as refugees in Chitral.
} 
settings of Tajikistan and Afghanistan. Their one-time Chitrali employees are often attracted by the prospect of handsome U.S. dollar salaries to work in Afghanistan: well educated, and having been brought up with Afghans and speaking fluent Dari, Chitrali men are especially attractive candidates for these posts, and many now live and work in Kabul and Badakshan. ${ }^{20}$

\section{Insiders and Outsiders: Fighter Pilots, Red Army Soldiers, and Dushanbe}

\section{ArTISTS}

The remainder of this article will focus on the everyday negotiation of diversity in my main Chitral fieldwork site, Rowshan. Rowshan is a large and relatively prosperous village with a population of about 8,000 largely Khowar-speaking Ismai'li and Sunni Muslims. These people are mostly long-term Rowshan dwellers, but they also include more recent "incomers" from nearby villages that are less wealthy than Rowshan. Almost all Rowshan villagers own relatively small landholdings on which they grow subsistence crops of rice, wheat, and vegetables. There is also an expanding "new elite" of well-educated villagers employed by nongovernmental organizations and government offices within and beyond the region.

In what follows, I will focus on the forms taken by interactions between incomers and Rowshan people. Rowshan villagers referred to Afghans and Tajiks in their village as "outside people" (berieo roye) and "strangers" (nagoni). Many social scientists continue to depict refugees as rootless people, devoid of a particular national culture and, as a result, excluded from the national imaginaries of the countries in which they live. States and their publics consider them, in other words, an impure threat to what Liisa H. Malkki (1995) has termed the globally hegemonic "national order of things." For Malkki, such folk have one of two options: They must either create "nation-like" identities in order to forge for themselves a space in the "national order of things," or they must subvert it by emphasizing their "liminality." These arguments have been forcefully contested in recent years, most notably by Aihwa Ong, who suggests that Malkki fails to explore the "complex, ambiguous and interweaving processes that transform refugees back into citizens," noting that "particular states and their publics may be for and against refugee influx at different points of time" $(2003,78-79){ }^{21}$

\footnotetext{
${ }^{20}$ The role played by the Aga Khan Foundation in cultivating a transcultural world is particularly important. Many of the Chitralis currently employed in development posts in Afghanistan are employed by the Aga Khan Foundation. At the same time, I have met women from Tajikistan's Badakshan region who have been sponsored by the Aga Khan Foundation to undergo courses in health and education training in Chitral. Constraints of space prevent a detailed exploration of the institutional dimensions of transregional space-making here.

${ }^{21}$ The problems with conceptualizing refugee movements without considering their relationship to older forms of migration and mobility have also been challenged by refugee specialists working on Afghan refugees in Pakistan (see Connor 1989).
} 
Despite their use of the term "outsider," Rowshan people deploy a wide range of categories to describe the men from Afghanistan and Tajikistan living in their village. These diverse ways of imagining and categorizing refugees have major implications for shaping the nature of the interactions that take place between villagers and outside people and, therefore, Rowshan villagers' cosmopolitan "appreciation of ideas, things, and beings from many places" (Tsing 2006) in Rowshan.

Rowshan people's conceptualizations of "outsiders" are characterized by a very high degree of complexity (cf. de Munck 2005; Froerer 2006). There are three major categories of "outsiders" (nagoni) that are relationally referred to one another during everyday conversations between Rowshan villagers. First, there are Khowar-speaking people who have settled in Rowshan since migrating there from nearby villages. Second, there are people from "down Pakistan," especially Pashto-speaking Pukhtuns who live and work in the village, mostly as hawkers and shopkeepers. Third, there are those people whom Rowshan villagers describe as "doers of Farsi" (farsi korak) — these are the Dari- and Tajik-speaking refugees and laborers from Tajikistan and Afghanistan who are the central focus of this article.

These different types of "outsiders" are placed within a moral hierarchy that is known and understood by most Rowshan villagers. Villagers perceive different categories of outsiders as capable of bringing strikingly contrasting forms of immorality to village life. Pukhtuns are widely perceived as being the most dangerous type of stranger: They are associated with many types of criminality, notably theft, child snatching, and drug smuggling. ${ }^{22}$ In comparison to Pukhtuns, Rowshan villagers see Farsi-speaking "Tajiks" as less morally corrupting. Some Farsi speakers live with their families in Rowshan, where they own respectable businesses; many have lived in Chitral for up to thirty years and speak fluent Khowar. The ability of these "refugees" to speak Khowar is something that villagers contrast to what they perceive as the inability of Pukthuns to learn their civilized and sophisticated language. Villagers often say that Khowar and Farsi are closely related and both "sweet" (shireen) languages in a way that the "hard" $\left(\right.$ sakht) Pashto is not. ${ }^{23}$

Rowshan villagers, however, do not simply essentialize all Afghan refugees as "doers of Farsi" but also typify these folk on the basis of more finite distinctions. They categorize most "doers of Farsi" as one of two types. First, the term "Tajik" (tazhi) is widely used to refer to Farsi-speaking people from the Badakshan and Panjshir regions of Afghanistan. These people are often blamed for introducing

\footnotetext{
${ }^{22}$ Depictions of Pukhtuns as child kidnappers are of particular historical significance in South Asia, especially in urban settings such as Bombay, where "Pathans" also have a reputation for being especially brutal moneylenders and strikebreakers (see Chandavarkar 1998, 173; Bhattacharya 2006).

${ }^{23}$ On Khowar's interrelatedness to these regional languages, see Elena Bashir (1996), Rolf Thiel Endressen and John Chr. Kristiansen (1981), and Morgenstierne (1936).
} 
homosexuality (bachabazi) into the region, although this discourse is more widely articulated in Chitral's urban district headquarters, Markaz, than it is in village settings such as Rowshan. ${ }^{24}$ Second, Rowshan villagers deploy very different stereotypes to talk about another category outsiders who are, nevertheless, also said to be "doers of Farsi": "Wakhiks" are Wakhi-speaking Ismai'li people who have long migrated to Chitral largely as seasonal laborers (mazduran) from the Wakhan corridor, a valley that forms a narrow strip of Afghan territory between Pakistan and Afghanistan (see Kreutzmann 2003, 221). ${ }^{25}$ Wakhi is an Pamiri Iranian language, but it is different in significant ways from other languages spoken in Chitral and Badakshan. Wakhiks are said by Chitralis to be harmless simpletons (nacharagan) who have "nothing in their head" (kaka nikie). They are the upcountry hicks (sarhadi roye) against whom Rowshan villagers often define themselves as cultured (tazhibyi haftah) city-dwellers (shaharo roye) ${ }^{26}$ Chitralis also say, however, that they have lost many positive human qualities during the course of their long struggle to attain their lofty status as fully realized humans (insanan), but the simple honesty (sadahgi) of their forefathers remain clearly visible in the thinking and behavior of their Wakhik neighbors.

My Chitral friends spoke with the "doers of Farsi" in the village in Farsi, although among themselves, the "outsiders" talked in a very wide range of Pamiri Iranian languages, including Wakhi, Shughnani, Rushani, and Ishkashemi. They lived mainly in groups of as many as ten men in cramped rooms in the village's small bazaar that they rented from Rowshan people. Some of them lived alone or in pairs in village houses, where they also worked as agricultural laborers. Rowshan's bazaar, a largely deserted space after the evening prayers, was filled, between 1995 and 2002, until late into the night with the sound of Tajik and Afghan music played on petrol containers fashioned into a rabob, a type of Afghan string instrument by Wakhiks and other "doers of Farsi" inside the crowded rooms in the bazaar.

These "outsiders" did not, however, live lives confined to the small teahouses (chai khana) and rented rooms of Rowshan's dusty bazaar alone: Complex cultural and religious transactions also took place between Chitralis and "outsiders." Persianate cultural forms were not simply a preexisting feature of Rowshan cultural life — as a result of the interactions between villagers and outsiders, they also

\footnotetext{
${ }^{24}$ One reason for these differences in the perception of Afghan refugees may lie in the stricter ideas concerning sexual morality among urban Markaz dwellers compared to the village setting of Rowshan.

${ }^{25}$ About 50,000 Wakhi-speaking peoples live on both sides of the Afghanistan-Tajikistan border along the Wakhan corridor, Pakistan's northern areas (especially the upper zones of the Ishkoman and Hunza valleys), northern Chitrali villages, and in the town of Tashkurgan in China's Xinjiang region (Kreutzmann 2003, 220). On the Wakhan, see Shahrani (2002); for an account of life in a Wakhi community in northern Pakistan, see Sabine Felmy (1997). For a survey of Wakhi life strategies across the region, see Kreutzmann (2003).

${ }^{26}$ For a comparative study of the importance of tropes concerning the differences between city folk and upcountry hicks in Afghan storytelling, see Margaret A. Mills (1991).
} 
continually leaked into daily village experience and were rendered into a shared focus of identification. The Afghan and Tajik guests (тепи) were not treated simply as demeaning household servants, lowly immigrants in need of patronizing support, or amusing diversions from the monotony of daily village life. Rather, some Tajik men quickly earned a reputation for being cultured and creative, and many Rowshan villagers became close friends with the incoming "doers of Farsi." This was not as visible, however, in Chitralis' interactions with Pukhtuns traders and hawkers (alghani). The alghani were rarely, if ever, invited as guests or friends into Chitrali homes. On a number of occasions indeed, Pukhtun hawkers were forced to leave the village's hamlets after having been accused by Rowshan men of encouraging village women to waste their precious resources on useless trinkets.

Rowshan villagers chatted with Farsi-speaking men, introduced me to them as their friends, and even invited them into the intimate spaces of their family homes. They were also seen as a critical intellectual resource: They taught some villagers how to read Sufi books by Persian mystics such as Hafiz, Sa'di, and Shiraz. A particular visible space where Persianate cultural forms could clearly be seen leaking into village life was Rowshan's bakery shop, opened by refugees from Afghanistan's Panjshir Valley in 1998. Each afternoon, the shop would be full of village boys who gathered to learn Dari and recite verses from Farsi poems. One young Rowshan man in his early twenties, Zulfikar, generated such a passion for the study of Farsi that he even chose to embark on a master's degree in Persian literature at Peshawar University. Importantly, he was also able to persuade his parents of the worthiness of his subject by saying that he would easily find well-paid employment with a nongovernmental organization working with Afghan refugees in Peshawar. Afghans also contributed more widely to the cultural life of Rowshan. Juma Khan, an Ismai'li man in his early twenties from Afghanistan's Wakhan corridor who lived in Chitral between 1995 and 1997, frequently relayed reports about Sunni mujahidin hostility toward Wakhik Ismai'lis to his Chitrali friends. At the same time, during collective "Chitrali" evenings of music and dance, villagers often persuaded him to perform Afghan and Wakhi songs on his wooden flute.

Many men from Tajikistan earned reputations for being "artists." They were invited to paint the walls of Rowshan houses with mountain sceneries, depictions of deer and peacocks, and portraits of the current Aga Khan, Prince Karim. ${ }^{27}$ These wall murals were a significant innovation to the decorative standards of Rowshan homes. Hitherto, many Rowshan Ismai'lis had not even dared to display photographs of the Aga Khan inside their guesthouses for fear of being vilified as "idol worshippers" (bud parast) by Rowshan Sunnis, let alone paint

\footnotetext{
${ }^{27}$ There is also a convergence of both older traditions of Persianate miniature painting that were historically important in Tajikistan's Gorno-Badakshan region (Iloliev 2006) and newer forms of Soviet-inspired "Tajik" national art forms.
} 
full-scale portraits of him on their walls. Young Rowshan Sunni men, undergoing training in the Islamic sciences in Deobandi madrasas often say that the "kind angels of paradise" will never enter a house in which images of the human form are to be found. Wall paintings of the Aga Khan have the power to invoke even stronger emotions; they furnish evidence that Ismai'lis commit shirk, or associationism, by treating the Aga Khan as a kind of demigod. Framed photographs of the Aga Khan are often found in Ismai'li households, yet many Ismai'lis remove these from their guesthouses when they are expecting Sunni visitors known to hold uncompromising attitudes toward both images and Ismai'lis. This strategy of concealment, of course, is not applicable to wall paintings, which, therefore, embody the expression of Ismai'li forms of selfunderstanding in a shifting space located between the privacy of the home and the public of the bazaar.

Conversations about life in Tajikistan and Afghanistan were common between both Sunni and Ismai'li Rowshan villagers and Farsi-speaking outsiders. In these, the assumptions held by many Rowshan villagers about the monolithic "backwardness" (pasmandhagi) of Badakshan and its people were frequently challenged by the graphic accounts given by Tajikistan's "refugees" about life in their region. Sitting in small groups in village orchards, we were often told that Badakshan, like upper Chitral, was mountainous, remote, and populated predominantly by Ismai'li Muslims.

Yet Chitralis also learned from Tajik men that across the River Pyanj, a very different model of the Badakshani village was in place. In contrast to the stereotypes widely held by Chitralis about "backward" (pasmandah) Wakhiks, villagers in Tajikistan's Gorno-Badakshan Oblast enjoyed electricity and metaled roads that had been built by the Soviet government-such forms of "modernity" had yet to penetrate Rowshan village life. My Chitrali friends also discovered that the men now working as laborers in their fields had been engaged in very different forms of employment before the Soviet Union's breakdown. Rowshan's Tajikis told dramatic stories about how they had been parachuted as spies and translators into Afghanistan by the Soviet army. Through such conversations, Rowshan villagers gained insights into and made comparisons between the complexity of the wider setting in which they lived and the diverse types of modernizing transformations its people had experienced over the past century. Through these interactions, Rowshan people increasingly saw themselves as existing within a transnational realm where vernacular identities existed alongside a more expansive set of Persianate values, as well as the sometimes unifying and at other times divisive bonds of religion. ${ }^{28}$

\footnotetext{
${ }^{28}$ It is important to note as well that such extranational forms of identity imaginings have thrived in a broader national setting in which the Pakistan "state" has consistently sought to homogenize national identity along both ethnic and religious lines (see Ali 2005; Jaffrelot 2002).
} 


\section{The Chief Minister Is Coming: Please Move Inside!}

Nation-states, international organizations, and older and newer imperial formations have played and continue to play very different roles in the simultaneous production and division of this transregional space. A study of interactions between "refugees" and "local villagers" in Chitral would be incomplete, therefore, without a consideration of the role of "the state" in the regulation and surveillance of this movement. What I have found useful for understanding the production of actually existing forms of cosmopolitan practices in this geopolitically sensitive setting is that these are not merely the product of a contradiction between a distant state acting (or failing to act) on a remote locality. Rather, local "faces" of the "Pakistan state" are often themselves producers of complex forms of transregional identity.

Rowshan is relatively remote, yet there are law courts, a police station, and a deputy superintendent of police in the village. As has widely been noted, the police are never a monolithic force instrumentally responsive to central command but always firmly situated within particular social contexts (Chandavarkar 1998, 15). In Rowshan, I suggest, they did not merely imagine refugees as dangerously destabilizing and polluting influences on the bounded certainties of village life. Rather, new interactions that took place between the "state" and the "refugees" did so in a space richly invested with the imprint of shared forms of sociocultural values concerning the status of the refugees as guests, co-religionists, friends, laborers, and the possessors of shared histories. This played a critical role in shaping the interactions between the Chitrali faces of the Pakistan state and the refugees.

The legal status of "outside people" was a source of confusion in the village. In December 1995, for instance, the chief minister of Pakistan's North-West Frontier Province was planning a visit to Rowshan. Such a high-level state visit to Chitral is relatively rare, and when such events do occur, they entail considerable levels of security and displays of protocol: A police escort accompanies the chief minister everywhere he goes. Many Rowshan people told me that they were worried that the police accompanying the chief minister would see the illegal Tajiks and deport them. Unlike Rowshan's several Afghan refugee families who held identity cards, the men from Tajikistan were not able to secure legal documentation within Chitral and were often too frightened to make the long journey to "Pakistan" in order to do so.

The men from Tajikistan were aware of their legally precarious position in Rowshan. As a matter of routine, they avoided going to the region's administrative headquarters because they feared being detained by the Chitral police there. One Wakhi-speaking man in his late forties whom I met in Tajikistan in October 2005 had worked and lived with a Seyyid family in Rowshan for five months. During this period, he had only been to Markaz once, and even on that occasion, he had been too scared to walk around the bazaar, for fear of being caught by the 
police; instead, he stayed put in the vehicle in which he traveled. There is also a police station (thana) in Rowshan, yet this man and others told me that they did not fear Rowshan's police. Indeed, he told a gathering of neighbors in his village in Tajikistan's Wakhan corridor that on the day he had left Rowshan for Tajikistan, not only had a village policeman helped him find a vehicle that was going to the northern Afghan border, but also he told the driver that his passenger that day was simple, poor, and going home with gifts for his family — under no circumstances, therefore, should he be asked for a fare.

Collaborations between Chitral's police, villagers, and the incoming Tajiks sometimes took a bigger and more significant form. One day before the chief minister's visit in December 1995, for example, Rowshan's deputy superintendent of police, at the time a bearded Sunni man from Markaz who could usually be seen in the early evening fingering his prayer beads and sauntering toward the mosque, drove his police vehicle around the village and publicly announced on a loudspeaker that any people from Tajikistan staying in the village who did not hold identity cards should not go to the bazaar but instead stay with Rowshan families the following day. If not, they risked being deported to their homes and also getting Chitral's police into great trouble. Rowshan people frequently invoke the great sacrifices (qurbani) they have made for their Tajik brothers (brargini) and guests: "Chitrali hospitality," thus, led both to an open-endedness of individual subjectivity that promoted interactions with Farsi-speaking outsiders, and it also allowed Chitralis to draw boundaries around more exclusive forms of cultural "intimacy" (Herzfeld 1997, 47-48).

The collaborations that took place between Rowshan's police force, villagers, and refugees clearly challenge, in Ong's words, any simple notion that refugees and citizens are inevitably related to one another as "irreconcilable opposites" (2003, 70). Refugees interact not with faceless states that exist outside local contexts but with institutions that are "deeply imbued" with "socio-cultural values" (79) and, I suggest, embedded within particular historicosocial spaces. The "state" is multiply constituted, and its faces engage with "refugees" through different matrixes that include but are not defined by the logics of national inclusion alone. These different and intensely local "faces of the state" (Navaro-Yashin 2002) are clearly imbued with sociocultural values that both provide the basis for the cosmopolitan appreciation and engagement with people from very different backgrounds but also construct boundaries around more vernacular forms of shared selfhood and community.

\section{We Are Not Wakhik! Transnational Muslim Identifications}

Far from provoking the emergence of de-cultural and avowedly religious forms of Muslim identity, Rowshan's refugees, I have argued, facilitated a range of older and newer forms of cultural interchange and contributed to Chitral's status 
as a transregional setting in which the everyday practice of coexistence with Afghan and Tajik incomers is one important cosmopolitan dynamic. When Chitralis shared their homes, engaged in conversations, and sought out these men as their friends, they were interacting with people who, for example, had experiences of work and education in the Soviet world. It would be misleading to think, however, that the cosmopolitan appreciation for diversity that is a visible feature of Rowshan village life only informs the lived nature of relationships between villagers and incomers, and therefore is generated by an external impulse or even global force that has instrumentally forged a break in the local subjectivity of Chitrali people. Rather, many Chitralis are aware of their families' own transregional pasts. ${ }^{29}$ So I will now explore the role played by older and newer forms of transregional mobility in the personal and family narratives of Chitralis today. My broader aim, though, is not merely to contest the status of "the nation" in the identity imaginings of the region's people or to question its "naturalness" as a category of analysis (Gupta 1992, 64; Van Schendel 2002b, 139). Rather, I ask in what ways people's older experiences of mobility in a culturally complex transregional space shape their current experiences, understandings, and strategies of negotiation with what today are transnational flows (Shami 2000, 189).

Rowshan villagers recognized that the flows of Afghan and Tajik people into their village were a product of the collapse of the Soviet Union and the disintegration of the Afghan state. Yet these movements of people were also talked about in terms of their relationship to older patterns of migration in the region. Rowshan Chitralis often tell me that most of their region's people are the descendents of both Farsi- and Wakhi-speaking "Afghans." They also have an in-depth historical awareness about these migrations. One woman, now aged in her early seventies, told me that her father, along with his wife and two children, had fled the Wakhan corridor in order to avoid being forced to join the Afghan army. Historians have documented, indeed, the social dislocations caused by the attempts of successive Afghan emirs and leadersnotably Abdur Rahman Khan-to weaken the authority of Badakshan nobility and extend the authority of the "Afghan state" in the region (cf. Schomberg 1935, 268; Shahrani 2002). ${ }^{30}$ This woman's parents and many other Wakhiks

\footnotetext{
${ }^{29}$ The Pakistan-Afghanistan border (known as the Durand line) was established in 1893, while the Wakhan corridor (intended as a buffer zone between Russia and British India) was mapped in 1895. For an account of the mapping of these borders, see Algernon Durand (2001). Political anxieties about the porousness of the Afghanistan-Pakistan border have been a marked feature of relationships between the two countries over the past fifty years. During the 1960s and 1970s, political tensions between Afghanistan and Pakistan heightened as a result of fears by the Pakistan government of the Afghan state's role in the sponsoring of a movement for the creation of Pashunistan. These issues remain important today: In 2007, Pakistani president Pervez Musharraf claimed that he intended to fence the Pakistan-Afghanistan border in order to prevent the incursion of Taliban fighters from Pakistan into Afghanistan.

${ }^{30}$ Norwegian linguistic scholar Georg Morgenstierne also documented the continuing influx of Wakhiks into Chitral during his first visit to the region in 1929 (see Morgenstierne 1932, 68).
} 
settled in Chitral and were gradually incorporated into the region's fluid and changing system of status hierarchy. Some of the Afghan incomers, especially those from more noble backgrounds, were presented with gifts of land (mehrabani zameen) by the Mehtar of Chitral; others became the serfs (chirmuzh) and servants (khanazad) of Chitrali gentry families. ${ }^{31}$

The forms taken by Chitralis' narrations of their own transregional pasts vary greatly and have very different implications for local forms of self-understanding. Folk from relatively high-status backgrounds claim descent from noble families that were once influential in the court of Badakshan, until they fell out of favor with the realm's monarch, or mir. Muhsin, a Sunni Chitrali man in his mid-thirties, told me that his grandfather came to Chitral from Badakshan after having had a dispute with the mir of Badakshan. His grandfather was apparently welcomed to Chitral by the Mehtar of the time, who gave him land and even arranged for him to marry a local girl. As a child, Muhsin often traveled to Badakshan in order to visit his relatives; during the course of these visits, he learned to speak fluent Dari. In Chitral, however, Muhsin and all his brothers say they are Chitrali, speak Khowar, and have married Chitrali women. Nevertheless, they are now reactivating their familial ties in Afghanistan. Muhsin's brother, Sajjid, traveled to Kabul in 2004 with the aim of finding employment as a vehicle mechanic in the city's rapidly expanding nongovernmental sector. In Kabul, he stayed with some of his Afghan relatives who were originally from Badakshan but had moved to Kabul in the 1970s. Muhsin himself had worked as a tour guide for foreign journalists: He took journalists across Afghan Badakshan and simultaneously built up an expansive network of connections with the region's mujahidin commanders. In later years, he used his in-depth knowledge of Badakshan's conflicts to secure legal residency status as an Afghan refugee in a European country.

The reactivation of ties with Afghanistan by Chitrali families was not, then, simply confined to Chitralis hosting Afghan "refugees" in their houses. Many Chitralis have visited Afghanistan over the past two decades. Their travels, I now suggest, play an active role in making and sustaining their place in what

Wakhi-speaking people I met in Tajikistan also told me that families from their villages had fled to Chitral on their region's incorporation into the Soviet Union. Douglas Northrop (2004) also highlights the importance of movements of people, things, and idea across the Soviet-Afghanistan border in the early years of the Soviet Union.

${ }^{31}$ An anonymous reviewer for the Journal of Asian Studies brought my attention to the degree to which the colonial state may have played an active role in persuading the rulers of Chitral and other princely states in modern-day northern Pakistan to gift land to Afghans who emigrated from their home region's after both the third Afghan war and the expansion of Soviet Union into southern Tajikistan. This article's focus on the present-day modes of understandings deployed by Chitralis to think about their transregional pasts prevents a more detailed exploration of this issue. Nevertheless, during future research, I hope to pursue this line of historical enquiry in greater detail. Ghulam Murtaza also documents Chitral's Mehtar, between 1856 and 1892, granting Ismai'li Seyyids from Badakshan "asylum" and property following an "onslaught" by Amir Abdur Rahman Khan (Murtaza $1982,223)$. 
I am calling a Persianate cultural zone. ${ }^{32}$ Travel is a well-documented dimension of Indo-Persian literary culture (Alam and Subrahmanyam 2004)-tales of journeys (safar) are also a frequent source of Chitrali conversation. ${ }^{33}$ The mother of the Ismai'li Seyyid family with whom I stay, now in her early sixties, often tells me that her mother was from Badakshan and spoke fluent Farsi, but only very rough (shum) Khowar. She was the daughter of well-known and influential family of Badakshani Ismai'li Seyyids who was given in marriage to Chitrali Sunni gentry family. This Seyyid family hails from cluster of villages known as Zebak, and they are widely respected as pirs by many Ismai'li throughout Chitral, Badakshan, and southern Tajikistan, where they have vast networks of followers (muridan).

After the withdrawal of Soviet forces from Afghanistan in 1989, the eldest son in the household, Ameen, made an epic two-month horseback journey to visit the house of his maternal grandmother, as well as to find a Badakshani horse, renowned in Chitral for being excellent for high-altitude polo. Ameen continues to tell stories rich with vivid images about the authority of the pir of Zebak, who had, indeed, presented him with gifts of horses, yaks, and cows. Since the early 1920s, when Bombay-based Ismai'li "community" leaders actively sought to strengthen their channels of communication with Chitrali Ismai' lis, the authority to transmit both the edicts or farmans of the Aga Khan and Ismai'li religious knowledge more generally, has, in Chitral, become increasingly the preserve of the Ismai'li Tariqa Board. This is the international Ismai'li body that coordinates, among other things, the religious education of the world's Ismai'lis. In contrast, the spiritual authority of Afghanistan's pirs remained far less contested by global developments in the organization of the world's Ismai'lis until the U.S.-led defeat of the Taliban in 2001-02, which made it possible for Ismai'li institutions to play a more significant role in the transmission of religious knowledge to Ismai'lis within Afghanistan.

Ameen's accounts of Badakshani religious life emphasize the differences that he saw in the form of religious authority in Chitral and Badakshan. They amount to a close and almost ethnographic description of this familiarly exotic realm. Ameen also shared much information about the current nature of Ismai'li experience in Badakshan with his fellow Rowshan people: He told his fellow Ismai'li village people that he had seen the Sunni mujahideen beating up Badakshani Ismai'li villagers, thereby sharing with fellow villagers firsthand knowledge about the Afghan refugees currently staying in their houses and working in their fields.

The presence of Afghan refugees in Rowshan thus reactivated Chitrali kinship connections with Afghanistan and memories of transregional family

\footnotetext{
${ }^{32}$ For studies of the complex, changing and dynamic ways in which premodern Persianate influences have shaped modern Iran, see Afsaneh Najmabadi (2005) and Kathryn Babayan (2002).

${ }^{33}$ On travel and mobility in the Muslim world, see Dale F. Eickelman and James Piscatori (1990).
} 
histories. This process of reactivation, however, was not always a sweetly reasonable one. The descendents of the "servants" of Chitral's one-time gentry-like families have invested considerable energy into concealing their Wakhik family backgrounds. For such folk, the historical consciousness of Chitral's connections with the wider region can undermine their attempts to transform their position in Chitral's shifting system of status hierarchy.

Pachambeh Khan, a man from Zebak in his mid-thirties who fled Afghan Badakshan complaining of the cruel treatment of Ismailis there by powerful Sunni mujahideen commanders, stayed with a Rowshan family who were the descendents of mid-twentieth-century Ismai'li migrants from Badakshan. This family is poor by Rowshan standards: Fourteen people in total, they live in a small house, own very little land, and, when Pachambeh Khan was staying with them, none of the family members held paid employment. Pachambeh Khan was a well-incorporated feature of this family's life, however. The family's three daughters, all of marriageable age, did not observe purdah before him; they also cared for him when he fell ill-purportedly because he had fallen in love with a beautiful Chitrali girl from a nearby hamlet. The intimate nature of this family's relationship with Pachambeh Khan the Zebaki was the cause of much discussion in Rowshan. This family's decision to host Pachambeh Khan "proved," according to one man with whom I spoke, who at the time was in his mid-eighties and from a wealthy and onetime lordly family, that these folk were not real (asil) Rowshan people at all but "dirty Wakhiks" (wahluchi wakhi). When I visited him in his home, he often told me that these families had once been "homeless beggars" (gadai tesh mashkak) until they were given enough land on which to survive by Rowshan villagers.

Talking about extra-Chitrali family backgrounds is a sensitive dimension of village conversation, which is important because of its role in local understandings of Afghan, Tajik, and Wakhi "others." Equally important, however, are the ways in which such conversations feed into the construction of shared forms of Chitrali selfhood and the internal divisions, boundaries, tensions and ambiguities surrounding authenticity that are central to these. Having and admitting to a transregional past may confer prestige, knowledge of distant places and conditions, and access to unique forms of spiritual insight. Yet it may also be unwelcome proof of a family's low status in the past, their tenuous claims to the village's land and its water resources, and the possibility that the moral unit of the village is being threatened by the presence of insincere interlopers bent on concealing their hybrid pasts.

These dualistic understandings of transregionality, "openness," and "closedness"- what Ho refers to as "dynamic signification" that marks the "movements of individuals" and presides over "the coming and goings of numerous persons across space, time and culture" $(2006,115)$ —illustrates the extent to which some Chitralis contrast their cosmopolitanism with others who cannot or have not participated in such forms of mobility. At the same time, it also points 
toward the ways in which Chitralis make finite distinctions between different forms of transregional mobility and the types of people who undertake them. While some types of mobility, when undertaken by men from lordly or religious families, are glamorous, personally enriching, and motivated by noble causes, others are practiced by the wrong people, for the wrong reasons, and in the wrong way. Villagers whose family members had once served as the laborers and domestic servants of the region's lordly families, a practice transformed though not eliminated by introduction of government land reform legislation in the 1970s, are especially open to such accusations of improper mobility.

The narration, therefore, of twentieth-century histories of movement from the Wakhan to Chitral is a matter of extreme sensitivity in Rowshan today. Indeed, many people go to great lengths to deny that they are Wakhiks at all—one woman who had migrated with her father to Chitral as a young child frequently became angry with villagers if they said she was Wakhik. Since I first visited Chitral in 1995, I have often talked with Rowshan villagers about their extra-Chitrali origins, yet it is only in recent years that I have heard stories about my friends' "Wakhik" grandparents. One man in particular, Lablabu Khan, has given me many insights into this domain of Chitral life and history. In his early forties, and from a village in a Chitrali village close to Afghanistan, Lablabu now lives in Rowshan, where he is low-grade government employee. His wife's mother came to Chitral from the Wakhan when she was ten years old-her father, she told me, was fleeing conscription in the Afghan army. His mother-in-law worked in the household of one of the region's gentry-like families. Then, as now, her family lived on a small plot of land, which they had been "given" by the lordly family for whom they worked. In recent years, they, like many other such Chitrali families, have benefited from the opportunities for social mobility provided to Chitralis by raising literacy levels, employment in the local wing of the Pakistan army (the Chitral Scouts) and police, and labor migration to Pakistan's cities. Two of her sons, although not formally educated, became junior commissioned officers in the Chitral Scouts until they retired and built impressive houses on land overlooking not only their ancestral home but also that of their onetime lords; her other two sons work as medical technicians in Karachi's prestigious Aga Khan University.

Lablabu Khan often tells me that he considers talking about matters of status, family descent, and hierarchy to be a highly impolite feature of Chitrali conversation (mashkulque). Hearing conversations about such matters, he tells me, makes his brain "cook" and go "mad." When staying in Rowshan in order to undertake his duties in the government department for which he works, he stays in small house built of mud bricks on land owned by his boss. He frequently complains that although his boss is kind and honorable, this man's nephews treat him as their uncle's serf, constantly asking him to do odd jobs and provide them with bottles of home-brewed raisin wine (kishmish orgh) without payment. These requests are a source of great irritation to Lablabu's eighteen-year-old daughter, 
educated as far as higher secondary level, who frequently tells her father that he should refuse to work for this family for free and consider them his equals and not his bosses (lalan).

The relatives of the pir of Zebak often told Rowshan villagers and me proudly about their connections in Afghanistan. They presented themselves as people with historically significant pasts that connect them to different places and mean that they are familiar with "conditions and personalities" (Ho 2006, 115) beyond the immediate setting of Rowshan and Chitral. Lablabu Khan, in contrast, urged me to write about and bring to the surface the cruel ways in which Chitralis talked about Wakhiks. In so doing, he highlighted his own recognition of the dynamic tension between "openness and closedness" (Ho $2006,198)$ that is a prominent feature of the cosmopolitan discourses of Chitral's higher-status transregional families. In contrast to Rowshan's Seyyid families, then, men such as Lablabu Khan consider the reactivation of memories about familial connections with Afghanistan and the Wakhan to be sensitive and even dangerous - they have the capacity to undo the active and often disappointed attempts made by such men to transform their families' place in Chitral's shifting system of status and descent.

Interactions between Chitralis and refugees invoked different types of transnational self-understanding that were weighted with importance for different reasons. Some villagers have openly sought to reactivate their ties with Afghanistan and sometimes even treated these as a critical economic resource. The presence of Afghan refugees from Badakshan stimulated some Chitralis to travel to Afghanistan, not to fight in the country's jihad but to visit their relatives. The capacity to make such journeys, enjoy the hospitality and even command the respect of distant relatives, and display the gifts with which they were presented, was a source of glamour for Rowshan villagers. Others, in contrast, have sought to suppress their connections with the wider Farsi-speaking world: Being labeled an Afghan by one's fellow Chitralis also has very negative implications for certain groups of people in Chitral today.

\section{Conclusion}

Over the past thirty years, Chitrali villages have employed post-Soviet Tajik men in their fields, learned Dari from Afghans, and embarked on journeys to their ancestral villages in northeastern Afghanistan. All this movement between deeply connected yet also discontinuous settings has stimulated practices of cosmopolitanism that valorize people's ability to move with art and skill across their wider world. These cosmopolitan practices are neither the onedimensional products of civil war nor the straightforward outcomes of global migration. They bear the imprint, rather, of older cultural influences-Persianate practices of travel, for example. Both nation-states and foreign powers frequently 
interpret these patterns of mobility and the relations they forge between Muslims from apparently incompatible backgrounds as a dangerous source of instability. Yet local faces of the Pakistan state collaborate with the region's mobile Muslims, while some international nongovernmental organizations have also sought to instrumentally generate transregional forms of connectivity.

In short, the intimate relations and ever-changing life histories and experiences of people in this region illuminate much about their experiences of some of the most momentous events of the past three decades, the effects of these on the relationships between these transregional societies, and people's ways of being Muslim. The multidimensional ways of being Muslim documented here should certainly not be seen in terms of their unbounded fluidity. Nor have no Muslims in the region embraced radical ways of acting within and against the world around them. Rather, people living in this expansive transregional setting frequently shift between very different indexes and ways of being Muslim during the course of their daily lives. In so doing, they forge intricate, intimate, and dynamic relations with other Muslims, not only from different places, ethnolinguistic groups, or confessional backgrounds, but also with very different life histories and personal experiences of this transregional space. Importantly, most of the region's Muslims do not simply "smooth over" their experience of this complexity by adhering to rule-bound forms or "de-culturalized" forms of "global" Islam (Ossman 2007, 8). Rather, these relations lead to the production of intertwining forms of complicity and critical engagement with the forces behind the momentous changes that the region's people have experienced over the last thirty years. The indexes of being Muslim that the region's people enact are cross-cut by competing forms of sectarian, social, and ethnolinguistic distinction; they also bear the imprint of the differential effects of both British and Soviet Imperial expansion. Resultantly, as Muslims move between their region's different spaces, they identify with very different values, traditions and things-some of which stand in stark contrast to one another. Sulton, for example, joined the Taliban but did not refashion his Muslim self according to ultra-orthodox forms of doctrinal Islam. Instead, he tactically switched between different ways of being Muslim, and, in the course of doing so, he identified with a homogenous Ismai'li community, the Sunni Taliban, and a local smuggler of apricot schnapps.

These shifting ways of being Muslim and the modes of identification they stimulate are thus always about more complex processes than the ways in which Muslims attach meanings to their “identities." Rather, Muslims living in this transregional setting fashion personal ways of being Muslim that are richly informed by and facilitate projects of identification with a diverse range of intellectual, cultural, and aesthetic influences and standards. These include local musical traditions that build on an expansive Persianate Sufic poetic heritage and Persianate styles of miniature painting that have interacted with Socialist art genres. The modes of identification that such ways of being Muslim stimulate, therefore, are richly nourished by complex processes of interaction and 
exchange. Thus, in this connected yet discontinuous cultural, political, and religious setting in which transregional forms of mobility are a pervasive feature of everyday life, I have focused on the everyday factors that lead people to enact—although not necessarily embrace — shifting political, religious, and moral orientations or dispositions at contingent historical and personal junctures and in particular places.

\section{Acknowledgments}

This paper would not have been possible without the generous hospitality and kindness of many people in Chitral, Afghanistan, and Tajikistan, notably Mir Hussein Shah and his family in Chitral; Aka Hussein, Sarkar Baig, Abdul Iloliev, and their families in Tajikistan; and Sultan Mahmood, Allah Nazar, Mukhtar Ameen, Mujib Jan, and their families in Afghanistan. I have also benefited from the insightful comments and criticisms of Ben Hopkins, Humeira Iqtidar, and Mathew Carey, as well as seminar audiences at the Centre of South Asian Studies, University of Cambridge; Department of Social Anthropology, Brunel University; and the Leeds University South Asian Studies seminar. Pseudonyms are used for all people and small places.

\section{List of References}

Abbasi-Shavazi M. J., and Glazebrook D. 2006. Continued Protection Sustainable Reintegration: Afghan Refugees and Migrants in Iran. Kabul: Afghan Research and Evaluation Unit.

Akiner, Shirin. 2002. Tajikistan: Disintegration or Reconciliation. London: Royal Institute of International Affairs.

Akiner, Shirin, Mohammad-Reza Djalili, and Frederic Grare. 1996. Tajikistan: The Trials of Independence. London: RoutledgeCurzon.

Alam, Muzaffar. 2004. The Languages of Political Islam: India, 1200-1800. London: Hurst.

Alam, Muzaffar, and Sanjay Subrahmanyam. 2004. "Comparative Studies of South Asia." Africa and the Middle East 24 (2): 61-72.

- 2007. Indo-Persian Travels in the Age of Discoveries, 1400-1800. Cambridge: Cambridge University Press.

Ali, Daud. 2004. Courtly Culture and Political Life in Early Medieval India. Cambridge: Cambridge University Press.

Ali, Kamran Asdar. 2005. "Courtesans in the Living Room." Institute for the Study of Islam in the Muslim World Review 15: 32-33.

Appadurai, Arjun. 1996. Modernity at Large: Cultural Dimensions of Globalization. Minneapolis: University of Minnesota Press.

Babayan, Kathryn. 2002. Mystics, Monarchs, and Messiahs: Cultural Landscapes of Early Modern Iran. Cambridge, Mass.: Harvard University Press.

Bashir, Elena. 1996. "The Areal Position of Khowar: South Asian and Other Affinities." In Proceedings of the Second International Hindukush Cultural Conference, ed. Elena Bashir and Israr-ud-Din, 167-79. Karachi: Oxford University Press. 
Bayly, Susan. 2004a. "Imagining 'Greater India': French and Indian Visions of Colonialism in the Indic Mode." Modern Asian Studies 38 (3): 703-44.

. 2004b. "Vietnamese Intellectuals in Revolutionary and Postcolonial Times." Critique of Anthropology 24 (3): 320-44.

Becker, Seymour. 1968. Russia's Protectorates in Central Asia: Bukhara and Khiva, 1865-1924. Cambridge, Mass.: Harvard University Press.

Bhattacharya, Neeladri. 2006. "Predicaments of Mobility: Peddlers and Itinerants in Nineteenth-Century Northwestern India." In Society and Circulation: Mobile People and Itinerant Cultures in South Asia, 1750-1950, ed. Claude Markovits, Jacques Pouchepadass, and Sanjay Subrahmanyam, 163-214. New Delhi: Permanent Black.

Biddulph, John. 1972 [1880]. Tribes of the Hindu Kush. Lahore: Ali Kamran.

Blank, Jonah. 2001. Mullahs and the Mainframe: Islam and Modernity among the Daudi Bohras. Chicago: University of Chicago Press.

Bowen, John R. 1989. "Salat in Indonesia: The Social Meaning of an Islamic Ritual." Man 24 (4): 600-619.

. 1998. "What Is Universal and Local in Islam?" Ethos 26 (2): 258-61.

Canfield, Robert L. ed. 1991. Turko-Persia in Historical Perspective. Cambridge: Cambridge University Press.

Chandavarkar, Rajnarayan. 1998. Imperial Power and Popular Politics: Class, Resistance, and the State in India, c. 1850-1950. Cambridge: Cambridge University Press.

Cole, Juan R. 2002. "Iranian Culture and South Asia, 1500-1900." In Iran and the Surrounding World: Interactions in Culture and Cultural Politics, Nikki R. Keddie and Rudi Matthee, 15-35. Seattle: University of Washington Press.

Collective for Social Science Research. 2006a. Afghans in Pakistan: Broadening the Focus. Kabul: Afghanistan Research and Evaluation Unit.

- 2006b. Afghans in Peshawar: Migration, Settlement and Social Networks. Kabul: Afghanistan Research and Evaluation Unit.

Connor, Kerry M. 1989. "Factors in the Residential Choices of Self-Settled Refugees in Peshawar, Pakistan." International Migration Review 23 (1): 904-32.

Daftary, Farhad. 1990. The Ismailis: Their History and Doctrines. Cambridge: Cambridge University Press.

- 1998. A Short History of the Ismailis. Edinburgh: Edinburgh University Press.

Das, Veena, and Deborah Poole, eds. 2004. Anthropology in the Margins of the State. Oxford: James Currey.

Decker, Kendall D. 1992. Languages of Chitral. Islamabad: National Institute of Pakistan Studies, Quaid-i-Azam University, and Summer Institute of Linguistics.

DE Munck, Victor C. 2005. "Sakhina: A Study of Female Masculinity in a Sri Lankan Muslim Community.” South Asia Research 25 (2): 141-63.

Didier, Brian J., and Edward, Simpson. 2005. "Islam along the South Asian Littoral." International Institute for the Study of Islam in the Modern World Review 16: 42-43.

Durand, Algernon. 2001. The Making of a Frontier: Five Years' Experiences and Adventures in Gilgit, Hunza, Nagar, Chitral, and the Eastern Hindu Kush. Karachi: Oxford University Press.

Edwards, David B. 1990. "Frontiers, Boundaries and Frames: The Marginal Identity of Afghan Refugees.” In Pakistan: The Social Science Perspective, ed. Akbar S. Ahmed, 61-99. Karachi: Oxford University Press.

—. 1994. "Afghanistan, Ethnography, and the New World Order." Cultural Anthropology 9 (3): 1-16. 
Ehmadi, Hafizullah. 1993. "Minority Group Politics: The Role of Ismailis in Afghanistan's Politics." Central Asian Survey 12 (3): 689-716.

. 1998. "The End of Taqiya: Reaffirming the Religious Identities of Ismailis in Shughnan, Badakshan-Political Implications for Afghanistan." Middle Eastern Studies 32 (3): 687-716.

Eickelman, Dale F., and James Piscatori. 1990. Muslim Travellers: Pilgrimage, Migration, and the Religious Imagination. Berkeley and Los Angeles: University of California Press.

Endressen, Rolf Thiel, and Knut Kristiansen 1981. “Khowar Studies.” Acta Iranica 21: $210-14$.

Engineer, Asghar Ali. 1989. The Muslim Communities of Gujarat: An Exploratory Study of Bohras, Khojas, and Memons. Delhi: Ajanta.

Felmy, Sabine. 1997. The Voice of the Nightingale: A Personal Account of the Wakhi Culture in Hunza. Oxford: Oxford University Press.

Ferguson, James. 1999. Expectations of Modernity: Myths and Meanings of Urban Life on the Zambian Copperbelt. Berkeley and Los Angeles: University of California Press.

Froerer, Peggy. 2006. "Emphasising 'Others': The Emergence of Hindu Nationalism in a Central Indian Tribal Community." Journal of the Royal Anthropological Institute 12:39-59.

Gidwani, Vinay, and Sivaramakrishnan K. 2003. "Circular Migration and Rural Cosmopolitanism." Contributions to Indian Sociology 37 (1-2): 339-67.

Gommans, Jos. 2002. Mughal Warfare: Indian Frontiers and Highroads to Empire, 15001700. London: Routledge.

Goodman, Bryna. 2000. "Improvisations on a Semicolonial Theme, or, How to Read a Celebration of a Transnational Urban Community." Journal of Asian Studies 59 (4): 889-926.

Grant, Bruce. 2005. "The Good Russian Prisoner: Naturalising Violence in the Caucasus Mountains." Cultural Anthropology 20 (1): 39-67.

Gupta, AкніL. 1992. "The Song of the Non-Aligned World: Trans-National Identities and the Reinscription of Space in Late Capitalism.” Cultural Anthropology 7 (1): 63-79.

Habibi, Gulbaden, and Pamela Hunte. 2006. Afghan Returnees from NWFP, Pakistan, to Nangarhar Province. Kabul: Afghanistan Research and Evaluation Unit.

Hannerz, Ulf. 1996. Transnational Connections: Culture, Peoples, Places. London: Routledge.

Herzfeld, Michael. 1997. Cultural Intimacy: Social Poetics in the Nation-State. London: Routledge.

Ho, Engseng. 2002. "Names beyond Nations: The Making of Local Cosmopolitans." Études rurales 163-64: 215-32.

— 2004. "Empire through Diasporic Eyes: A View from the Other Boat." Comparative Studies in Society and History 46:210-246.

- 2006. The Graves of Tarim: Genealogy and Mobility across the Indian Ocean. Berkeley and Los Angeles: University of California Press.

Holzwarth, Wolfgang. 1996. "Chitral History, 1540-1660: Comments on Sources and Historiography”. In Proceedings of the Second International Hindukush Cultural Conference, ed. Elena Bashir and Israr-ud-Din, 116-34. Karachi: Oxford University Press.

Hopkins B. D. Forthcoming. "Race, Sex and Slavery: 'Forced Labour' in Central Asia and Afghanistan in the Early 19th Century." Modern Asian Studies. 
Humphrey, Caroline, Magnus Marsden, and Vera Skirvskaja. Forthcoming. "Cosmopolitanism and the City: Interaction and Co-existence in Bukhara." In The Other Global City: Living Together in Asia, ed. MayaramShail. London: Routledge.

Hunsberger, Alice C. 2000. Nasir Khusraw, The Ruby of Badakshan: A Portrait of the Persian Poet, Traveller and Philosopher. London York: I.B. Tauris/Institute of Ismaili Studies.

Hutt, Michael. 2005. Unbecoming Citizens: Culture, Nationhood, and the Flight of Refugees from Bhutan. New Delhi: Oxford University Press.

Iloliev, Abdul. 2006. "Poetic Expression of Pamiri Ismāīlism: The Life and Thought of Mubārak-i Wakhānī, a Nineteenth-Century Mystic Poet and Religious Scholar.” PhD diss., Cambridge University.

IUCN Pakistan. 2004. Chitral: A Study in Statecraft (1320-1969). Karachi: IUCN Pakistan. http://www.iucn.org [accessed October 10, 2007].

Jaffrelot, Christophe, ed. 2002. Pakistan: Nationalism without a Nation. London: Zed Books.

Kepel, Gilles. 2002. Jihad: The Trail of Political Islam. London: I.B. Tauris.

Khalid, Adeeb. 2007. Islam after Communism: Religion and Politics in Central Asia. Berkeley and Los Angeles: California University Press.

Kreutzmann, Hermann. 2003. "Ethnic Minorities and Marginality in the Pamirian Knot: Survival of Wakhi and Kirghiz in a Harsh Environment and Global Contexts." Geographical Journal 169 (3): 215-35.

Launay, Robert. 1992. Beyond the Stream: Islam and Society in a West African Town. Berkeley and Los Angeles: University of California Press.

Malkki, Lissa H. 1995. Purity and Exile: Violence, Memory, and National Cosmology among Hutu Refugees in Tanzania. Chicago: Chicago University Press.

Mandaville, Peter G. 2004. Transnational Muslim Politics: Reimagining the Umma. London: Routledge.

Marsden, Magnus. 2005. Living Islam: Muslim Religious Experience in Pakistan's NorthWest Frontier. Cambridge: Cambridge University Press.

Metcalf, Barbara D. 1999. "Nationalism, Modernity, and Muslim Identity in India before 1947." In Nation and Religion: Perspectives on Europe and Asia, ed. Peter van der Veer and Hartmut Lehmann, 129-43. Princeton, N.J.: Princeton University Press.

Mills, Margaret A. 1991. Rhetorics and Politics in Afghan Traditional Storytelling. Philadelphia: University of Pennsylvania Press.

Mir, Farina. 2006. "Genre and Devotion in Punjabi Popular Narratives: Rethinking Cultural and Religious Syncretism." Comparative Studies in Society and History 48 (3): 727-58.

Monsutti, Alessandro. 2006. Afghan Transnational Networks: Looking beyond Repatriation. Kabul: Afghan Research and Evaluation Unit.

Morgenstierne, Georg. 1932. Report on a Linguistic Mission to North-Western India. Cambridge, Mass.: Harvard University Press.

—. 1936. "Iranian Elements in Khowar." Bulletin of the School of Oriental Studies 8 (2-3): 657-71.

Murtaza, Ghulam Mirza. 1982. New History of Chitral. Based on the original Persian text of Mirza Muhammad Ghufran; revised and enlarged with additional research of Late His Highness Sir Nasir-ul-Mulk by Mirza Ghulam Murtaza. Trans. Wazir Ali Shah. Chitral, n.p.

Najmabadi, Afsaneh. 2005. "Mapping Transformations of Sex, Gender and Sexuality in Modern Iran.” Social Analysis 49 (2): 54-77. 
Nasr, Vali. 2005. "National Identities and the India Pakistan Conflict." In The IndiaPakistan Conflict: An Enduring Rivalry, ed. T. V. Paul, 178-201. Cambridge: Cambridge University Press.

—. 2006. The Shia Revival: How Conflicts within Islam Will Shape the Future. New York: W.W. Norton.

Navaro-Yashin, Yael. 2002. Faces of the State: Secularism and Public Life in Turkey. Princeton, N.J.: Princeton University Press.

Noelle, Christine. 1997. State and Tribe in Nineteenth-Century Afghanistan: The Reign of Amir Dost Muhammad Khan (1826-1863). Richmond: Curzon Press.

Northrop, Douglas. 2004. Veiled Empire: Gender and Power in Stalinist Central Asia. Ithaca, N.Y.: Cornell University Press.

Ong, Ainwa. 2003. Buddha Is Hiding: Refugees, Citizenship, the New America. Berkeley and Los Angeles: California University Press.

Osella, Filippo, and Caroline Osella. 2007. "I Am Gulf”: The Production of Cosmopolitanism in Kozhikode, Kerala, India." In Struggling with History: Islam and Cosmopolitanism in the Western Indian Ocean, ed. Edward Simpson and Kai Kresse. London: Hurst.

Ossman, Susan. 2007. Places We Share: Migration, Subjectivity, and Global Mobility. Lanham, Md.: Lexington Books.

Parkes, Peter. 2000. "Enclaved Knowledge: Indigent and Indignant Representations of Environmental Management and Development among the Kalasha of Pakistan.” In Indigenous Environmental Knowledge and Its Transformations: Critical Anthropological Perspectives, ed. Roy Ellen, Peter Parkes, and Alan Bicker, 253-91. Amsterdam: Harwood Academic.

. 2001a. "Alternative Social Structures and Foster Relations in the Hindu Kush: Milk Kinship and Tributary Alliance in Former Mountain Kingdoms of Northern Pakistan." Comparative Studies in Society and History 43 (1): 4-36.

_ 2001b. "Unwrapping Rudeness: Inverted Etiquette in an Egalitarian Enclave." In An Anthropology of Indirect Communication, ed. Joy Hendry and C. W. Watson, 232-51. London: Routledge.

Pelkmans, Mathijs. 2006. Defending the Border: Identity, Religion, and Modernity in the Republic of Georgia. Ithaca, N.Y.: Cornell University Press.

Pollock, Sheldon. 2000. "Cosmopolitan and Vernacular in History." Public Culture 12 (3): 591-625.

—. 2004. "Forms of Knowledge in Early Modern South Asia: Introduction." Comparative Studies of Africa, South Asia and the Middle East 24 (2): 19-21.

Roy, Olivier. 1994. The Failure of Political Islam. London: I.B. Tauris.

- 2004. Globalized Islam: The Search for a New Ummah. London: Hurst.

Roy, Olivier, and Mariam Авоu Zанав. 2004. Islamist Networks: The Afghan-Pakistan Connection. London: Hurst.

Schomberg R. C. F. 1935. Between the Oxus and the Indus. London: M. Hopkinson.

Shahrani M. Nazif. 1984. "Causes and Contexts of Responses to the Saur Revolution in Badakshan." In Revolutions and rebellions in Afghanistan: Anthropological Perspectives, ed. M. Nazif Shahrani and Robert L. Canfield, 139-69. Berkeley: Institute of International Studies, University of California, Berkeley.

. 1991. "Local Knowledge of Islam and Social Discourse in Afghanistan and Turkistan in the Modern Period." In Turko-Persia in Historical Perspective, ed. Robert L. Canfield, 132-60. Cambridge: Cambridge University Press.

_ 1995. "Afghanistan’s Muhajirin (Muslim "Refugee-Warriors"): Politics of Mistrust and Distrust of Politics.” In Mistrusting Refugees, ed. E. Valentine Daniel and 
John Chr. Knudsen, 187-206. Berkeley and Los Angeles: University of California Press.

2002. [1979]. The Kirghiz and Wakhi of Afghanistan: Adaptations to Closed Frontiers and Wars. Seattle: Washington University Press.

Shami, Seteney. 2000. "Prehistories of Globalization: Circassian Identity in Motion." Public Culture 12 (1): 177-204.

Shin, Shu-Mer. 1996. "Gender, Race and Semicolonialsm: Liu Na’ou’s Urban Shanghai Landscape." Journal of Asian Studies 55 (4): 934-56.

Simpson, Edward. 2006. Muslim Society and the Western Indian Ocean: The Seafarers of Kachchh. London: Routledge.

Soares, Benjamin F. 2005. Islam and the Prayer Economy: History and Authority in a Malian Town. Edinburgh: Edinburgh University Press.

Spooner, Brian. 1993. “Are We Teaching Persian? Or Farsi? Or Dari? Or Tojiki?” In Persian Studies in North America: Studies in Honor of Mohammad Ali Jazayery, ed. Mehdi Marashi, 175-90. Salt Lake City: University of Utah Press.

Staley, John. 1982. Words for My Brother: Travels between the Hindu Kush and the Himalayas. Karachi: Oxford University Press.

Stigter, ElCA. 2005. Transnational Networks and Migration from Herat to Iran. Kabul: Afghan Research and Evaluation Unit.

Tambiah, Stanley J. 1976. World Conqueror and World Renouncer: A Study of Buddhism and Polity in Thailand against a Historical Background. Cambridge: Cambridge University Press.

Tsing, Anna. 2002. "Conclusion: The Global Situation." In The Anthropology of Globalization, ed. Jonathan Xavier Inda and Renato Rosaldo, 433-85. Oxford: Blackwell. . 2005. Friction: An Ethnography of Global Connection. Princeton, N.J.: Princeton University Press.

Turton, David, and Peter Marsden. 2002. Taking Refugees for a Ride: The Politics of Refugee Return to Afghanistan. Kabul: Afghanistan Research and Evaluation Unit.

Van Schendel, Willem. 2002a. "Geographies of Knowing, Geographies of Ignorance: Jumping Scale in Southeast Asia." Environment and Planning D: Society and Space 20: 647-68.

—. 2002b. "Stateless in South Asia: The Making of the India-Bangladesh Enclaves." Journal of Asian Studies 61 (1): 115-47.

Werbner, Pnina. 1999. "Global Pathways: Working Class Cosmopolitans and the Creation of Transnational Ethnic Worlds." Social Anthropology 7 (1): 17-37.

—. 2004. Pilgrims of Love: The Anthropology of a Global Sufi Cult. London: Hurst.

Wilson, Thomas M., and Hastings Donnan. 1998. "Nation, State and Identity at International Borders." In Border Identities: Nation and State at International Frontiers, ed. Thomas M. Wilson and Hastings Donnan, 1-30. Cambridge: Cambridge University Press. 